\title{
Tocharian B Manuscripts in the Berezovsky Collection (2): Five More Fragments ${ }^{1}$
}

Abstract: This article is a full edition of five Tocharian B manuscripts kept in the Berezovsky sub-collection of the Serindia Collection of the IOM, RAS: two Sanskrit-Tocharian B Bilingual Udānavarga fragments (Uv. 1.26b-1.34a, Uv. 4.23b-4.34c); a SanskritTocharian B Bilingual Karmavācanā (Upasampadā) fragment, one fragment of a jātaka and one fragment of a stotra previously erroneously identified as Udānastotra. The article contains a transliteration, transcription, tentative translation as well as a commentary on the text of the fragments.

Key words: Udānavarga, Karmavācanā, Sanskrit-Tocharian B bilingual, textual and manuscript studies, textology, manuscriptology

In a previous article ${ }^{2}$, I have made a start with publishing fragments from the Berezovsky collection of the Institute of Oriental Manuscripts of the Russian Academy of Sciences (IOM, RAS). This article continues publication of the Tocharian B manuscripts from this collection, presenting five more manuscripts: two Tocharian B - Sanskrit bilingual fragments of the Udānavarga $^{3}$; one fragment of the Tocharian B - Sanskrit Karmavācanā; one fragment of a jātaka; and one fragment previously erroneously identified as belonging to the Udanastotra.

(C) Lundysheva Olga, Junior Researcher of the Laboratoria Serindica, IOM, RAS (olgavecholga@gmail.com)

${ }^{1}$ I would like to thank Georges-Jean Pinault for his valuable assistance in editing these manuscripts. Likewise, I would like to thank Michaël Peyrot for his great support and advice and help in editing.

${ }^{2}$ LUNDYSHEVA 2019.

${ }^{3}$ For details on the publication of the Udānavarga, cf. PEYROT 2008a, PEYROT 2016a. For details on the publication of the Udānavarga from the Serindian collectiom of the IOM, RAS, cf. OGIHARA 2016. Two more fragments were recentely published by OGIHARA 2018, LUNDYSHEVA 2019. 
Symbols used in transliteration and transcription

() restoration

[ ] uncertain reading

\{\} later addition

- $\quad$ one unreadable akșara

- unreadable consonantal or vocalic part of an akșara

III torn edge of a fragment

- $\quad$ dot, punctuation mark

: $\quad$ double dot, punctuation mark (mostly metrical)

ś and other underlined consonants represent so-called Fremdzeichen

a $\quad$ so-called Fremdvokal, equivalent to $\ddot{a}$

r、 consonant in virāma position (without dot, mostly with Fremdzeichen consonant)

c; consonant in virāma position with dot (mostly with Non-Fremdzeichen consonant $)^{4}$

\section{Karmavācanā fragment, Upasạ̣padā}

SI 2922/2 (Old number: B/3 (14-2)

Findspot: Kuča, On-baš ${ }^{5}$ Min-Öy

Bilingual Tocharian B/Sanskrit

fig. 1

fig. 2

SI 2922/2 fragment gives a text which is nearly identical to one of the Berlin version of the Karmavācana (Staatsbibliothek Preußischer Kulturbesitz), THT 1102-1125, which belongs to the Sarvāstivādin school. To be precise, the text corresponds to leaf No. 16 of the Berlin manuscript $(=\text { THT } 1108)^{6}$, lines a2-b3.

\footnotetext{
${ }^{4}$ When a Fremdzeichen consonant is following under a Non-Fremdzeichen consonant in virāma position a virama with dot is used as well.

${ }^{5}$ Mikhail Berezovsky registered all the find spots of the manuscripts. He labelled this find spot "Onbašskii Minui". However, the place is presently difficult to identify. All we know about it with certainty is that it was situated near Kucha and it was a complex of cave temples = Min-Öy ("thousand caves") or "Minui" in Berezovsky's spelling.

${ }^{6}$ The text was read, restored and translated by Klaus T. Schmidt in a book which was submitted as Habilitationsschrift to Saarbrücken University in 1986. For a long time it remained unavailable in printed form. The edition (2012) given on the CEToM website (https://www.univie.ac.at/tocharian) is based on Schmidt's edition and provides photographs of the manuscript. The edition is now available in print: SCHMIDT 2018.
} 


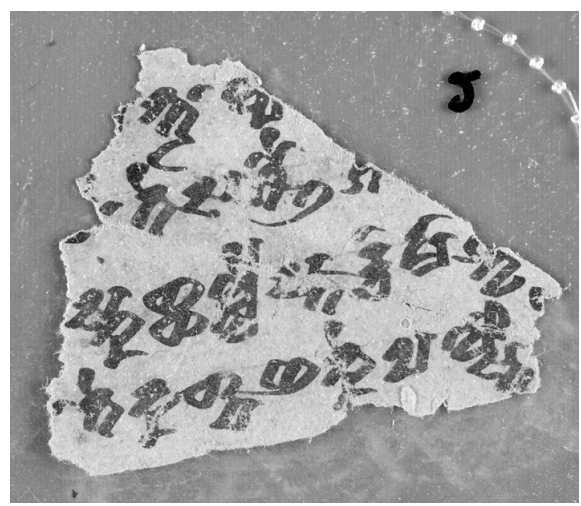

fig. 1: SI 2922/2 recto

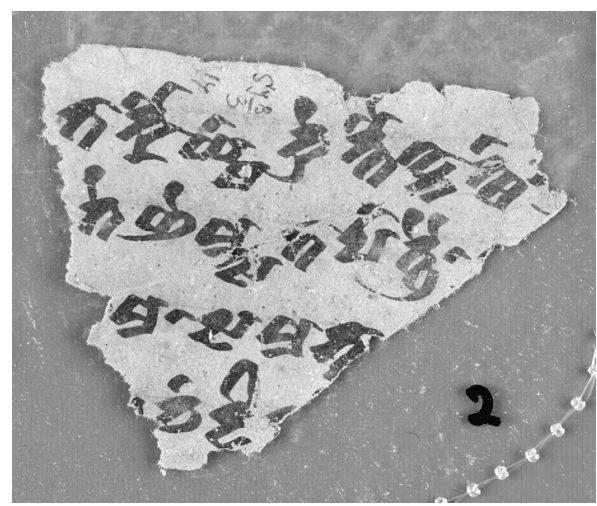

fig. 2: SI 2922/2 verso

\section{Material description}

Size ( $\mathrm{h} \mathrm{x} \mathrm{w}$, maximal): $3.7 \times 4.7 \mathrm{~cm}$. Fragment of the middle of a leaf. It is likely that the lower edge is visible on the recto side and the upper edge on the verso side. It is possible that the leaf had only four lines on each side.

\section{Transliteration}

a1 /// (.) $[p \cdot]^{7}$ ntra $\cdot l y \cdot / / /$

a2 /// [rc $\cdot]^{8} \cdot$ tesa śaul $s \cdot / / /$

a3 /// skașsalle star-c: $m \bar{a}$ św $/ / / /$

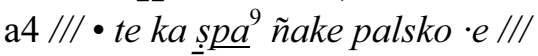

b1 /// tākoym; krentauwnats $;$

b2 /// te ñemtsa tā pāttrai $\bullet[\cdot r u]^{11} / / /$

b3 /// ma • saman $\cdot \bar{a} / / /$

b4 /// [e]vam d(·)i [r·] - ///

${ }^{7}$ The rest of the akșara before the lacuna is rather compatible with $<$ ma $>$ or $<$ pa $>$.

${ }^{8}$ The rest of the akșara is compatible with $<\mathrm{rc}>$ of line a3.

${ }^{9}$ There is no trace of any virāma stroke, even though șpä looks closely attached to the preceding letter. But it is for sure not written somewhat below the line.

${ }^{10}$ Judging from the level of the loop belonging to the presumable ligature $<$ tra $>$, it seems likely that the word was written with double /tt/, as in the next line pättrai.

${ }^{11}$ The rest of the akșara is compatible with $<\cdot$ ru $>$ because of the tiny remnant of the loop. It is supported by the text of THT 1108 . 


\section{Transcription}

a1 /// (war)p(a)nträ •ly ///

a2 /// (star)-c • tesa śaul ś(awașälle) ///

a3 /// (ya)skașsälle star-c mā św(ātsintse) ///

a4 ///• te ka șpä ñake palsko(n)e ///

b1 /// tākoym $(\bullet)^{12}$ krentauwnats p(ätt)r(o) ///

b2 /// te ñemtsa tā pāttrai • (p)ru(camñai) ///

b3 /// (ma)ma • $\operatorname{saman}(v) \bar{a}$ (hara) ///

b4 /// evam d(v)ir (api) ///

\section{Tentative translation}

a1....will enjoy...

a2. ...(this eating bowl) is to be (seized) by you. Thus [your] life should be lived (by you) ${ }^{13} \ldots$

a3. ...(you) should beg for it, (but you shall) not (for the sake of) food...

a4. ... and, indeed, this now in [your] mind...

b1....I wish to be, (I wish to be) a bowl of virtues...

b2. ...(I,) N.N., this excellent eating bowl...

b3. ... (it is) mine. Pay heed to this...

b4. ...thus the second [time]...

\section{Comments}

a1. Compare THT 1108 lines a 1-2 (pā)traiyne cene ompostäm tsan்kalyi wärpananträ lyec $\cdot / / /$.

Note that the subjunctive of wärpa - "to enjoy" in SI 2922/2 makes perfect sense in this context, because the passage refers to the future. The Berlin text has the apparent present warpananträ with irregular $a$ in the first syllable. Schmidt emends this to a regular $3 \mathrm{pl}$. present wärpananträ with $\ddot{a}$ in the first syllable, but in view of the reading in SI 2922/2, an emendation of the form in THT 1108 to warpanträ has now become more likely.

a2. Compare THT 1108 line a3 te p(ā)tr(o) è k(așalya) s(ta)r-(c) t(ai)sa śaul śawasäle star-cä.

\footnotetext{
${ }^{12}$ After a virama with dot a regular dot as punctuation mark was usually omitted in writing.

13 “Thus you shall earn (lit. live) [your] living" (CEToM).
} 
Note that there is no dot after the first sentence in the Berlin text. Furthermore, SI 2922/2 supports the restoration $t(e) s a$ in the Berlin text, which is allowed by the lacuna. The restoration $t$ (ai) $\mathrm{sa}^{14}$ should be abandoned. In SI 2922/2, the gerund form ought to be restored with $<1 l e>$, as in the next line.

a3. Compare THT 1108 line a4 tā pātrai(sa) y(a)skașsäle star-cä mā śwātsitse pernesa śaul śailyñe sparkäsäle star-cä. ${ }^{15}$

a4. Compare THT 1108 line a5 te ka sppä ñ(ak)e p(a)l(sk)one pyāmtsar.

b1. Compare THT 1108 line b1 (en̉ka)șșeñca tākoymä krentaunats $p(\bar{a} t) r(o$ tă) koymä.

b2. Compare THT 1108 line b2 (te) ñemts(a) tā pātrai prucamñai enkkaskemar solmīyai pātrai rșākäñ̃̃e bhajam. This is a word by word translation of a ritual phrase which was spoken in Sanskrit. Compare the following Sanskrit text (THT 1108 line b3) aham itthamnnāma (= te ñemtsa) idam pātram (=tā pātrai) pāribhogikam (= prucamñai) adhitișthāmi (= èkaskemar) paripūrnam (= solmīyai) pātram (= pātrai) rșibhājanam (= rșākäñ̃̃e bhajam).

b3. The following part contains the part of the ritual which was spoken in Sanskrit, except the imperative poñ 'say!'. Compare THT 1108 line b2 tavedam pātram poñ mama samanvāyușmām. ${ }^{16}$

Note that the parallel Berlin text has no dot after mama.

b4. Compare THT 1108 line b3 evam dvir api trrr api. ${ }^{17}$

\section{Notes}

This fragment belongs to a part of the ritual of ordination (upasampada-) for monks, more precisely to the episode concerning the acceptance of the alms bowl (pātra-) by the applying monk. This part follows the request and acceptance of the clothes (civara-) by the monk to be ordained. ${ }^{18}$

There are some differences of punctuation and orthography between the two manuscripts THT 1108 and SI 2922/2, which adds an interesting testimony to the ritual manuscripts for the Buddhist communities using Tocharian B.

\footnotetext{
${ }^{14}$ SCHMIDT 2018, 24, 56.

15 "You shall beg for [it] (with) this eating bowl. But you shall not, for the sake of food, let fade away [this way of] earning [your] livelihood" (CEToM).

16 "Is this your eating bowl? Say: [Yes, it is] mine. Pay heed to this, o venerable one!" (CEToM, somewhat modified).

17 "Thus a second [and] a third time" (CEToM).

${ }^{18}$ For the general context and background, cf. HÄRTEL 1956, 74-76.
} 


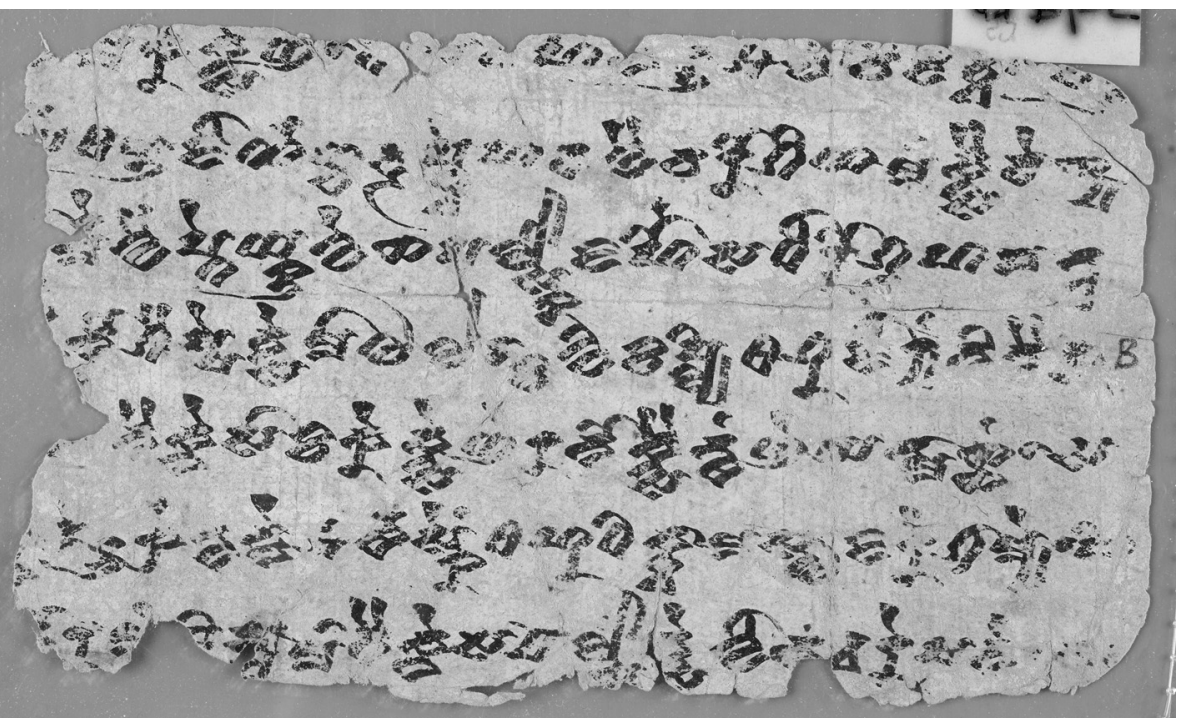

fig. 3: SI 2985/1 recto

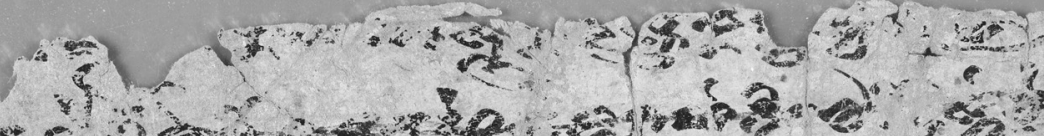
ps

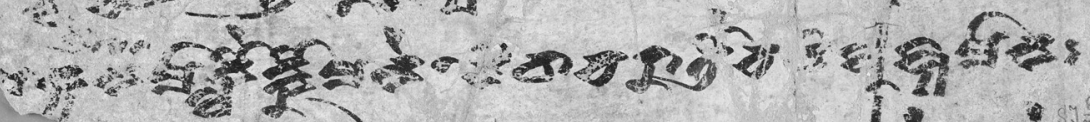

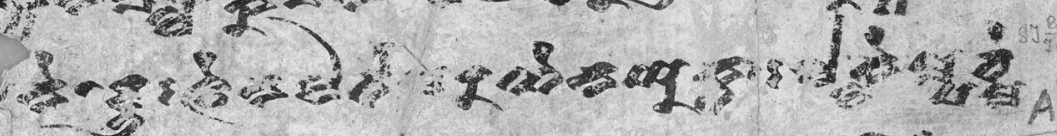

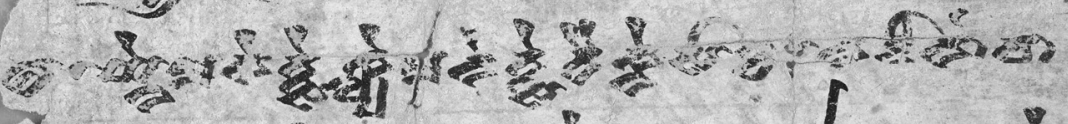

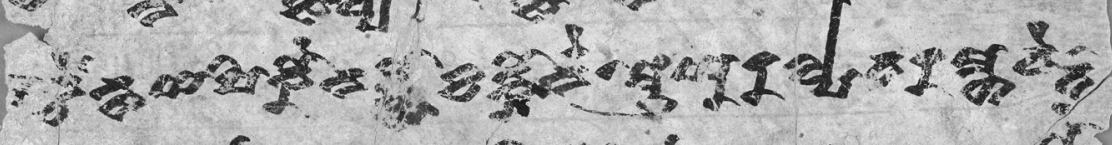

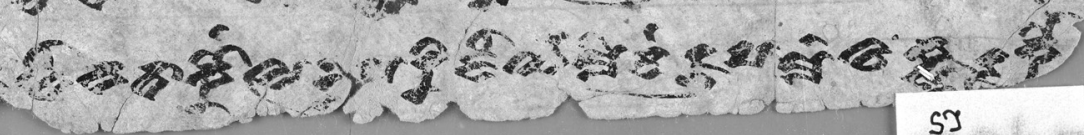
57

fig. 4: SI 2985/1 verso 
Udānavarga (Uv. $1.26 \mathrm{~b}-1.34 \mathrm{a})^{19}$

SI 2985/1 (Old number: B/75)

Findspot: Kuča, Tadjit ${ }^{20}$, main temple.

Bilingual Tocharian B/Sanskrit

fig. 3

fig. 4

SI 2985/1 lines b2-b4 give a text which is nearly identical with the Udānavarga manuscript Or.15007/308, kept in London (British Library), lines a1-a3. SI 2985/1 lines a4-a7 give a text which is nearly identical with the Udänavarga manuscripts IOL Toch. $233+$ IOL Toch. $368,{ }^{21} \mathrm{kept}$ in London (British Library), lines a1-a4. SI 2985/1 line a2 corresponds to the Udānālañkāra manuscript kept in Berlin (Staatsbibliothek Preußischer Kulturbesitz $)=$ THT $5,{ }^{22}$ line a1; line a5 to line a8; line a6 to line $\mathrm{b} 1$.

\section{Material description}

Size (h x w, maximal): $9.0 \times 15.5 \mathrm{~cm}$. The right part of a leaf. The lower and upper edges are visible. Seven lines are still visible on both sides, which must also have been the original size of the manuscript. Line b1 is damaged: the paper has been erased, and the ink has fainted.

\section{Transliteration}

$\underset{[\mathrm{ce}]_{u}^{25}}{\mathrm{a} 1 / / /[n] \cdot(\cdot) m \cdot(\cdot)^{23} k \cdot k t \operatorname{sen}()^{24} \cdot t \cdot[s] \cdot(\cdot) v \cdot h[\bar{a}] n \cdot[k] u s^{\prime} \cdot l[o] \operatorname{vid}[i] t v \cdot \bullet}$

${ }^{19}$ The numbering of the chapters follows BERNHARD 1965.

${ }^{20}$ Mikhail Berezovsky labelled this find spot "Tadjit - glavnyj xram" (Tadjit - main temple). It was situated near Kuča. According to Berezovsky there was in Tadjit a surface monastery as well as a complex of cave temples, a Min-Öy ("thousand caves"; "Minui" in Berezovsky's spelling).

${ }^{21}$ Published by PEYrot 2007.

${ }^{22}$ Published by Sieg \& SiEgling 1983, $147 \mathrm{ff}$.

${ }^{23}$ The Skt. absolutive prahayya corresponds to the Toch. B absolutive in -rmem. Therefore, $<\mathrm{r}>$ and $<\mathrm{m}>$ should be restored.

${ }^{24}$ A virāma with dot is supposed to be here after which a regular dot as a punctuation mark was omitted in writing. However, here one can see a regular dot as a punctuation mark and no virāma at all.

${ }^{25}$ The akșara traces are compatible with $<\mathrm{ce}_{\mathrm{u}}>$ of line a6. 


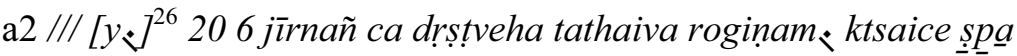

a3 //I ·[o]rme waipte ykuweșa palsko jahau sa dhìro g[r] habandha

a4 /// $\cdot[i]$ no śaișsentse mā olañk ${ }^{27}$ wikașlyi 207 jīryamt $i^{28}$ vai $[\mathbf{r a}]^{29}$

a5 /// $[t \cdot]^{30}$ taiknesāk ${ }^{31}$ kektseñe rano ktsaitsamñe yanmāsssam $\bullet$ sa $^{32}$

a6 /// [·cn'ce] $]_{u}$ krentanne śarsaskem 208 dhik tvām astu jare grāmye $\cdot$ hi

a7 //I [n] $]^{33}$ oramam bimbam; taiknesa pals $\cdot$ ontse wina erepate $\cdot[\text { jara }]^{34}$

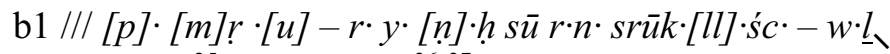

b2 /// kall \{ $\tilde{n}^{35}$ \}eścä aiwol ${ }_{i}{ }^{36}{ }^{37}$ anu hy e[na]m jarā hamti $\bullet$ o[·p]ostam ce ${ }_{u}$

b3 /// ș[e]k yanem mā klautkomane ${ }^{38} \cdot$ divā ca rātrau ca [vi]lujyamāna ${ }^{39}$ h

b4 /// [m· ne • duhkhena jātīmarañena ${ }^{40}$ yuktāh laklempa cme

b5 /// tha $\bar{a}^{41} \cdot$ ynemanentse klyemanentse taiknes $\bar{a} \underline{k_{(}}{ }^{42} \cdot$ nadīnām vā

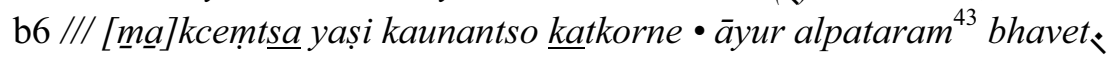

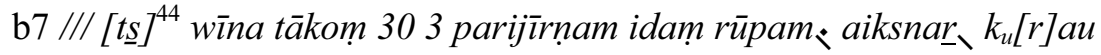

${ }^{26}$ See in the comment section.

${ }^{27}$ There is a tiny trace on the akșara $<$ la $>$ which looks like a beginning of virāmaconnection with the following $<$ ńka $>$ like in IOL Toch. 702 line b1. However, in the parallel text IOL Toch. $233+368$ line a1, one reads olank $\ddot{a}$ without virāma; and also here, the akșara $<$ nka $>$ is not lowered.

${ }^{28}$ In the parallel text IOL Toch. $233+368$ line a1, one can see jīryanti.

${ }^{29}$ This akșara should be the $<\mathrm{ra}>$ of rājarathāh Uv. 1.28a.

${ }^{30}$ This akșara should be the $<\mathrm{ti}>$ of upaiti Uv. $1.28 \mathrm{~b}$.

${ }^{31}$ One can suppose that in this akșara $<\overline{\mathrm{a}}>$ diacritical mark is used as a virāma-connection for the following Fremdzeichen consonant $<\underline{\mathrm{k}}>$.

${ }^{32}$ This akșara should be the $<\mathrm{sa}>$ of satām Uv. $1.28 \mathrm{c}$.

${ }^{33}$ This akșara should be the $<\mathrm{n} \cdot>$ of manoramam Uv. $1.29 \mathrm{c}$.

${ }^{34}$ The akșaras are reconstructed according to the Sanskrit text of Uv. 1.29d.

${ }^{35}$ The $<\tilde{n}>$ has been added under the $<$ lle $>$ later.

${ }^{36}$ Compare Or.15007.308 line al aiw.

${ }^{37}$ A virāma with dot is supposed to be after a non-Fremdzeichen consonant. So here one can suppose to see a virāma without dot and a dot as punctuation mark which are mixed in a unitary virāma with dot.

${ }^{38}$ Compare Or.15007.308 line a2 $n \cdot(m)$ mà klautk.

${ }^{39}$ In BERNARD 1965, 107: Uv. 1.31 b vilujyamānāh.

${ }^{40}$ Compare Or.15007.308 line a3 marane.

${ }^{41}$ This is the last akșara of tathā Uv. 1.32b.

${ }^{42}$ As in line a5, one can suppose that in this akșara $<\overline{\mathrm{a}}>$ diacritical mark is used as a virāma-connection for the following Fremdzeichen consonant $<\underline{k}>$. However, the is a possibility, that the word taiknesāk was spelled as taiknesākä.

${ }^{43}$ In BERNARD 1965, 108: Uv. 1.33a alpataram

${ }^{44}$ Acording to the sanskrit text a genetive plural ending of a pronoun is supposed to be here. The rest of akșara could be compared with $<$ tsä> of mäkcemtsä line b6. 


\section{Transcription}

a1 /// (reri)n(or)m(em) k(e)ktseñ • t(ām $\operatorname{sar}) v(a) h(\bar{a}) n(i m k) u s ́(a) l(o)$ $\operatorname{vid}(i) t v(\bar{a}) \cdot c e_{u}$ Uv.1.26b, c

a2 /// y 26 jïrnañ ca drșțveha tathaiva roginam ${ }^{45}$ ktsaice șpä Uv. 1.26d; Uv. $1.27 \mathrm{a}$

a3 I/I (lyelyak)orme«ṃ» waipte ykuweșä palsko jahau sa dhìro grhabandha Uv. $1.27 \mathrm{~b}, \mathrm{c}$

a4 /// (yśelm)i no śaiș̣entse mā olañk wikäslyi 27 jīryamti vai rā(jarathāh) Uv. $1.27 \mathrm{~d}$; Uv. $1.28 \mathrm{a}$

a5 /// taiknesāk kektseñe rano ktsaitsämñe yanmāșșäm • sa Uv. 1.28b, c

a6 /// (kreñ)c n(o) ce krentänne śarsäskem 28 dhik tvām astu jare grāmye • hi Uv. 1.28d; Uv. 1.29a

a7 /I/ (ma)noramam bimbam taiknesa pälskontse winna erepate - jara Uv. $1.29 \mathrm{c}, \mathrm{d}$

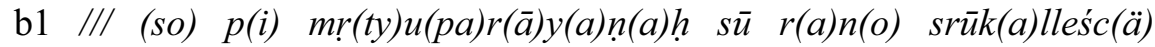
(ai)w(o)l Uv. $1.30 \mathrm{~b}$

b2 /// (sū rano srū)kallñeścä aiwol • anu hy enam jarā hamti • ompostäm $c e_{u}$ Uv. 1.30b, c

b3 //I șek yanem mā klautkomane - divā ca rātrau ca vilujyamānah Uv. $1.31 \mathrm{a}, \mathrm{b}$

b4 I/I (pälke)m(a)ne - duḥkhena jātīmaranena yuktāh laklempa cme Uv. $1.31 \mathrm{c}, \mathrm{d}$

b5 /// (ta)thā - ynemanentse klyemanentse taiknesāk • nadīnām vā Uv. $1.32 \mathrm{~b}, \mathrm{c}$

b6 //I mäkcemtsä yași kaunantso kätkorne - āyur alpataram bhavet Uv. $1.33 \mathrm{a}, \mathrm{b}$

b7 //I (ṃ)ts wīna tākom 33 parijīrnam idam rūpam aiksnar $k_{u}$ rau Uv. $1.33 \mathrm{~d}$, Uv. $1.34 \mathrm{a}$

\section{Reconstruction and tentative translation}

Uv. 1.26b /// (reri)n(or)m(em) k(e)ktseñ

sarve gamisyanti prahāya deham "[men] will all pass away, casting off [their] bodies."

Uv. $1.26 \mathrm{c} c e_{u} / / /$

tām sarvahānim kuśalo viditvā "the wise man [who] understands (lit. having seen) [that] the loss is complete"

\footnotetext{
${ }^{45}$ After a virama with dot a regular dot as a punctuation mark was omitted in writing.
} 
Uv. $1.26 \mathrm{~d} / / / y$

dharme sthito brahmacaryam careta "should live a life of purity (life of continence and chastity) according to the Law (steadfast in the Law)"

Uv. 1.27a ktsaice spä ///

jīrnañ ca drșțeha tathaiva roginam "seeing an old man here (= in this world), and likewise [seeing] a sick man" THT 5 a1

Uv. 1.27b /// (lyelyak)orme«ṃ» waipte ykuweșä palsko

mrtam ca drștvā vyapayātacetasam "seeing a dead man, abandoned [by] consciousness"

Uv. $1.27 \mathrm{~d}$ (yśelm)i no śaiṣsentse mā olankk wikäṣlyi IOL Toch. $233+$ IOL Toch. 368 a1

kāma hi lokasya na supraheyāh. "however, the desires of the world [are] not easily extinguished"

Uv. $1.28 \mathrm{~b}$ taiknesāk kektseñe rano ktsaitsämñe yanmāṣ̦äm IOL Toch. $233+368$ a2; THT 5 a8

hy atho sarìram api jarām upaiti "likewise, the body also gets old"

Uv. $1.28 \mathrm{~d}$ (kreñ) c n(o) ce krentänne śarsäskem THT 5 b1

santo hi tam satsu nivedayanti "and the virtuous men make it known among the virtuous men"

Uv. 1.29a hi(st) /// IOL Toch. $233+368$ a3

dhik tvām astu jare grāmye "shame on you, old and vulgar"

Uv. 1.29 c taiknesa pälskontse wina erepate IOL Toch. $233+$ IOL Toch. 368 a4

tatha manoramam bimbam. "since the form [that is so] lovely"

Uv. 1.30b (sū rano srūukallñeścä aiwol

so pi mrtyuparāyanah "Even that one [is] prone to death" Or.15007/308 a1

Uv. 1.30 c ompostäm ce ${ }_{u} / / /$

anu hy enam jarā hamti "and thus death follows old age (lit. old age kills)"

Uv. 1.31a șek yanem mā klautkomane Or.15007/308 a2

sadā vrajanti hy anivartamānā "perpetually they go (away) without returning (=die)"

Uv. 1.31c /// (pälke)m(a)ne

matsyā ivâtīva hi tapyamānā "like fish exceedingly burnt"

Uv. 1.31d laklempa cme ///

duhkhena jātimmaranena yuktāh "with the suffering of birth and death" Or.15007/308 a3

Uv. 1.32b ynemanentse klyemanentse taiknesāk

caratas tiștatas tatha "of the moving [one and] as also of the staying [one]" 
Uv. 1.33a mäkcemtsä yaṣi kaunantso kätkorne

yeșām rātridivāpāye "of [men] whose days and nights have passed"

Uv. $1.33 \mathrm{~d}(m)$ ts winna tākom

kā nu teșām ratir bhavet "what pleasure should they have (=find)"

Uv. 1.34a aiksnar $k_{u} r a u$

parijīnnam idạ rūpam "this completely old form (=body)"

\section{Comments}

a1. Toch. B kektseñ, obl. sg., "body"46 corresponds to Skt. deham, acc. sg., with the same meaning.

a1. The Skt. absolutive prahāya must be rendered in Toch. B with an absolutive in -ormem. According to the palaeographic traces, it is possible to restore (reri) [n]ormem "after having abandoned" (absolutive from rin- "renounce, abandon"), ${ }^{47}$ which is the expected translation of prahaya.

a1. Toch. B $c e_{u}$, obl. sg. masc., "that" corresponds to Skt. täm, acc. sg. fem., with the same meaning. Evidently, the Skt. feminine sarvahainim was in Toch. B rendered with a masculine or alternant noun, for instance a verbal noun in -lñe like nkelñe 'destruction' or kselñe 'extinction'.

a2. According to the akșara traces, Skt. careta, 3sg. optative, is rendered in Toch. B with a $3 \mathrm{sg}$. optative ending in $-y_{*}$.

a2. Toch. B ktsaice, obl. sg., "old age" from ksaitstse, ${ }^{48}$ corresponds to Skt. jīrnam "old age", acc. sg.

a2. Toch. B spä "and" corresponds to Skt. $c a$ with the same meaning.

a3. The Skt. absolutive drst via must correspond to a Toch. B absolutive in -ormem, so that the omitted $<m>$ is to be added. It is possible to restore (lyelya)kormem "after having seen" (absolutive of läk- "see, look at"), ${ }^{49}$ which makes perfect sense in this context.

a3. The Skt. compound vyapayātacetasam "[the one] whose mind has gone apart" was translated into Toch. B as a phrase: waipte ykuweșä palsko. The Skt. participle vyapayāta "gone away" is rendered as Toch. B waipte "apart, separately" and $y$ kuweșä "having gone", obl. sg. preterite participle from $i$ - "go, travel". ${ }^{50}$ Toch. B palsko, obl. sg., "mind" corresponds to Skt. cetasam, acc. sg., with the same meaning.

\footnotetext{
${ }^{46}$ ADAMs 2013, 202.

${ }^{47}$ ADAMS 2013, 581.

${ }^{48}$ ADAMS 2013, 263.

${ }^{49}$ ADAMS 2013, 596.

${ }^{50}$ ADAMS 2013, 65.
} 
a4. For Skt. kāmā, nom. pl., "desires, sexual pleasures" it is possible to restore Toch. B yśelmi, nom. pl., "(sexual) pleasure” from yśelme.

a4. Toch. B no "but, however" corresponds to Skt. $h i$ with the same meaning.

a4. Toch. B śaișsentse, gen. sg., "world" 52 corresponds to Skt. lokasya, gen. sg., with the same meaning.

a4. Toch. B $m \bar{a}$ "no, not" corresponds to Skt. $n a$ with the same meaning.

a4. The Skt. nom. pl. gerund supraheyāh " \pm perfectly dispatched" was translated into Toch. B as a phrase with olank "enough, easy" and the nom. pl. gerund wikäslyi from wik- "decrease and disappear". ${ }^{53}$

a5. Skt. $<$ hy $>$ is normally not translated. Rather, pada-initial $<$ hy $>$ is often left out in the Skt. parts of the bilinguals.

a5. Toch. B taiknesāk "thus, just so" ${ }^{, 54}$ corresponds to Skt. atho "likewise". a5. Toch. B kektseñe, nom. sg., "body" ${ }^{55}$ corresponds to Skt. baroram, nom. sg., with the same meaning.

a5. Toch. B rano "also" corresponds to Skt. api "also, moreover, surely".

a5. Toch. B ktsaitsämñe ${ }^{56}$ obl. sg., "old age" corresponds to Skt. jarām, acc. sg., with the same meaning.

a5. Toch. B yanmāșsämm, ${ }^{57}$ ssg. active present from yäm- "achieve, obtain; reach" ${ }^{, 58}$ corresponds to Skt. upaiti, 3sg. present, "reach, obtain, to get into any state or condition".

a6. Compare the beginning of the Toch. B part with THT 5 b1: kreñc no $c \cdot-$ krentämne śarsäskemne eñ(we)tsts(e).

a6. Toch. B kreñc, nom. pl. masc., "good"59 corresponds to Skt. santah, nom. pl. masc., "good, real, true; a good or wise man".

a6. Toch. B no "but, however" corresponds to Skt. $h i$ with the same meaning.

a6. Toch. B rano "also" corresponds to Skt. api "also, moreover, surely".

${ }^{51}$ ADAMS 2013, 565.

${ }^{52}$ ADAMS 2013, 696.

${ }^{53}$ ADAMS 2013, 652.

${ }^{54}$ ADAMs 2013, 325.

${ }^{55}$ ADAMs 2013, 202.

${ }^{56}$ The correct form is ktsaitstsäññe (ADAMS 2013, 263). However, in the parallel text IOL Toch. $233+368$ line a2, one can see ktsaitsäñ̃̃e as well.

${ }^{57}$ The correct form is $y \ddot{a} n m \bar{a} s \underline{s} \ddot{a} m$. One can see it in the parallel text IOL Toch. $233+368$ line $\mathrm{a} 2$.

${ }^{58}$ ADAMS 2013, 538 .

${ }^{59}$ ADAMs 2013, 153-154. 
a6. Toch. B $c e_{u}$, obl. sg. masc., "that" corresponds to Skt. tam, acc. sg. masc., "that".

a6. Toch. B krentänne, loc. pl. masc., "good" corresponds to Skt. satsu, loc. pl. masc., "good" etc.

a6. Toch. B śarsäskem, 3pl. active present from śärs- "to make known", corresponds to Skt. nivedayanti, 3pl. present, with the same meaning.

a6. The Toch. B part starts with hi. One can suppose hiśt "pfui, pooh"60 to be reconstructed as a rendering of the Sanskrit interjection dhik, or otherwise $h i s^{61}$ as in the parallel text IOL Toch. $233+368$ a3. This assumption is supported by THT 5 b8: hiśt $t^{62} t(w) e$ tākoyt (kts)aitsäñ̃̃e.

a7. Toch. B taiknesa "thus" corresponds to Skt. tathā "thus, in that manner".

a7. The Skt. adjective + noun phrase manoramam bimbam "charming, beautiful image" was translated by a Toch. B complex phrase with an element of composita pälskontse (gen. sg.) winna (nom. pl. ${ }^{63}$ ) erepate (nom. sg.) "form [which is] a pleasure for the mind".

b1. Toch. B sū, nom. sg. masc., "he, this one" corresponds to Skt. sah, nom. sg., with the same meaning. Toch. B rano "also" corresponds to Skt. api "also, moreover, surely". The Skt. compound mrtyuparāyanah "[the one who is] an aim of death" was translated into Toch. B as a phrase with srükalleścä, all. sg., "death"64 and aiwol "towards, directed to". ${ }^{55}$

b2. It looks like that the beginning of the line is a repetition of Uv. $1.30 \mathrm{~b}$ from the line b1, at least in Toch. B. However, for some reason the word srūkalleścä in the repetition was corrected by the subscription of $<\tilde{\mathrm{n}}>$ to the ligature $<$ lle $>$. It seems strange because there are two derivatives from sruk"die": ${ }^{66}$ srukalle as a noun and srukalñe as a verbal abstract. The combination of $<11 \tilde{n}>$ with double $/ 11 /$ before $/ \tilde{\mathbf{n}} /$ would be irregular. So this seems to be a scribal mistake.

b2. Toch. B ompostäm "afterwards" ${ }^{\prime 67}$ corresponds to Skt. anu "after, afterwards, thereupon". Skt. hy is not translated. Toch. B $c e_{u}$, obl. sg. masc., "that" corresponds to Skt. enam, acc. sg. masc., with the same meaning.

\footnotetext{
${ }^{60}$ ADAMs 2013, 797.

${ }^{61}$ Here his is written together with the following twe. So the last $<\mathrm{t}>$ of hist $t$ could be omitted.

${ }^{62}$ As the original manuscript was lost one cannot be sure about the omittance or presence of the final $\langle\mathrm{t}\rangle$ in the ligature.

${ }^{63}$ wina is a pluralia tantum (ADAMS 2013, 654).

${ }^{64}$ ADAMS 2013, 792.

${ }^{65}$ ADAMS 2013, 111.

${ }^{66}$ ADAMs 2013, 791-792.

${ }^{67}$ ADAMS 2013, 126.
} 
b3. Toch. B șek "continually, perpetually" corresponds to Skt. sadā with the same meaning.

b3. Toch. B yanem, 3pl. active present from $i$ - "go, travel" corresponds to Skt. vrajanti, 3pl. present, "go, work, proceed".

b3. Skt. hy is not translated.

b3. The Toch. B present participle klautkomane from klautk- "to turn, return, become" ${ }^{, 68}$ with negation $m \bar{a}$ corresponds to Skt. anivartamānā, nom. pl., "not returning to life, without return".

b4. The Skt. pl. participle tapyamāna corresponds normally to a Toch. B present participle in -mane, so that $<$ ma $>$ would seem to be the best option for the restoration of the preserved traces at the beginning of the line. The whole form may be pälkemane, as the Toch. B root corresponding to Skt. tap- "to make hot, to suffer pain, to torment oneself" is often pälk- "to burn; (caus.) torture". ${ }^{69}$ However, the rest of akșara does not look like $<\mathrm{m} \cdot>$ but more like $\langle\mathrm{y} \cdot\rangle$. If it is indeed $\langle\mathrm{m} \cdot\rangle$, the lower right part must have been lost completely through abrasion. This is certainly a possibility, because there is a tear in the fragment at exactly that place.

b4. Toch. B laklempa, com. sg., "suffering" ${ }^{\text {"70 }}$ corresponds to Skt. duhkhena, ins. sg., with the same meaning.

b4. Toch. $\mathrm{B}<\mathrm{cme}>$ should be the beginning of a derivative of the word camel "birth, rebirth" " $\mathrm{cmel}^{\circ}$, or the word cmelle/cmelne "birth, rebirth" nom./obl. sg. gerund from täm- "to be born"" with the same meaning.

b4. The Skt. compound jātīmarana may have been translated into Toch. B as cmelle srükalle as in Udānavarga manuscript PK AS 1A b1. The Skt. instrumental is rendered the with Toch. B comitative here so that one can restore cmelle srūkallempa.

b5. Toch. B ynemanentse, gen. sg. present participle from $i$ - "to go", corresponds to the Skt. present participle caratas, gen. sg., "moving".

b5. Toch. B klyemanentse, gen. sg. present participle from käly- "to stand", corresponds to Skt. present participle tiștatas, gen. sg., "standing".

b5. Toch. B taiknesāk "thus, just so" corresponds to Skt. tathā "thus, in that manner".

\footnotetext{
${ }^{68}$ ADAMs 2013, 248

${ }^{69}$ ADAMs 2013, 404.

${ }^{70}$ ADAMs 2013, 589.

${ }^{71}$ ADAMS 2013, 269.

${ }^{72}$ ADAMS 2013, 308.
} 
b6. The Toch. B gen. pl. reflexive pronoun mäkcemtsä corresponds to Skt. yeșām, gen. pl., "which".

b6. The Skt. compound rātridivāpāye, loc. sg., "passing of nights(s) and days(s)" was translated into Toch. B as a phrase with gen. pl. yași kaunantso ${ }^{73}$ "night(s) and days" and kätkorne, loc. sg. of the $r$-abstract from the preterite participle from kätk- "proceed, pass on, pass [of time]".

b7. Toch. B wina, nom. pl. (tantum), "pleasure" corresponds to Skt. ratih, nom. sg., with the same meaning.

b7. Toch. B tākom, 3pl. active optative from nes- "be, exist, become" ${ }^{\text {"74 }}$ corresponds to Skt. bhavet, 3sg. optative, "be, exist, become".

b7. Skt. parijīnnam, nom. sg., "old, decayed" is translated into Toch. B by a phrase with aiksnar "(al)toghether, completely" and $k_{u} r a u$, nom. sg. preterite participle of kwär- "to age, grow old". ${ }^{75}$

\section{Notes}

This fragment belongs to the first Udānavarga ${ }^{76}$ chapter named Anityavarga.

There are some differences between orthography and verbal forms of the two texts of IOL Toch. 233+368 and SI 2985/1. The translation from Sanskrit is done word by word. However, sanskrit compositas are usually translated by Toch. B phrases. Toch. B is not as rich in synonyms as Sanskrit is used to be. Some Skt. phrases get an additional elaboration as in line a7. All these instances helped not only to keep the translation close to the original but also make it clearer for the audience and omit excess stylistic effort.

Udānavarga (Uv. 4.23b-4.34c)

SI 2994/9 (Old number: SI B/114)

Find spot: Kuča, On-baš Min-Öy

Bilingual Tocharian B/Sanskrit

fig. 5

fig. 6

${ }^{73}$ In yași kaunantso, yași is in the singular and kaunantso is in the plural. We probably have to take it as a compound, even though no accent effect in yași is seen.

${ }^{74}$ ADAMs 2013, 366.

${ }^{75}$ ADAMS 2013, 254.

${ }^{76}$ For the general context, cf. ĀNANDAJOTI BHIKKHU, 2007. 


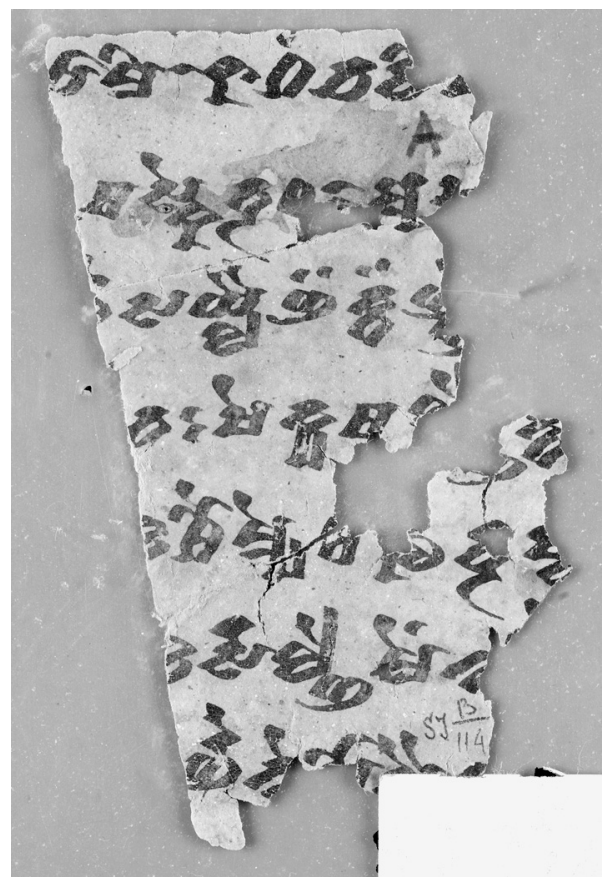

fig. 5: SI 2994/9 recto

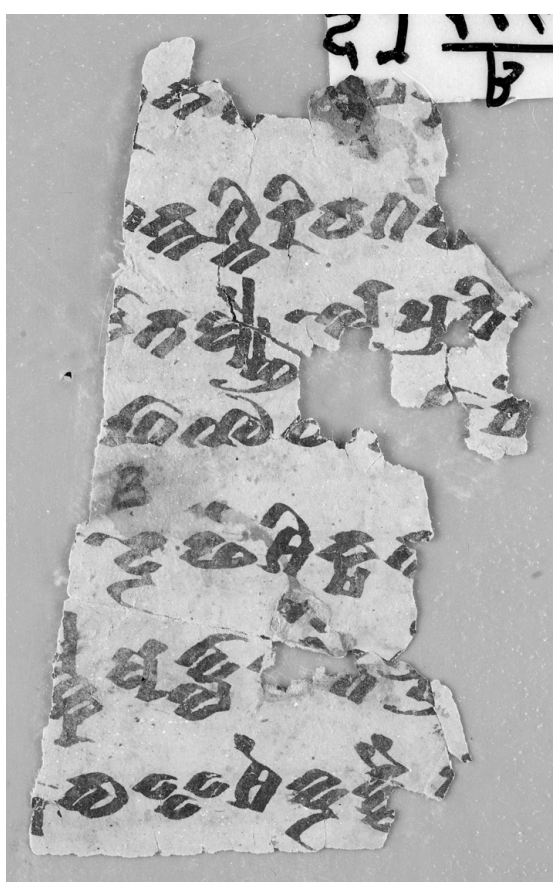

fig. 6: SI 2994/9 verso

\section{Material description}

Size (h x w, maximal): $8.2 \times 5.3 \mathrm{~cm}$. Fragment of the middle of a leaf. It is likely that the lower and upper edges are both visible. On the fragment, seven lines are still visible on both sides. One can assume that each side had seven lines. The fragment is heavily damaged. All the lines have losses of text.

\section{Transliteration}

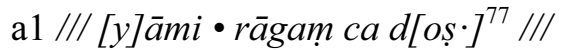

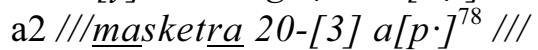

a3 /// [rñe] $]^{79}$ sa ylaiñäktäñ̃̃ $[e] / / /$

a4 /// ta ${ }^{80} h$ șek yamal $[y] \tilde{n} e n t \cdot / / /$

\footnotetext{
${ }^{77}$ These akșaras should be the $<$ doșa $>$ of doșam Uv. 4.23c.

${ }^{78}$ This akșara should be the <pra $>$ of apramādam Uv. 4.24a.

${ }^{79}$ The akșara is compatible with $<$ rñe $>$ of a7 line.

${ }^{80}$ Compare Berngard 1965, 134: Uv. 4.25b panditāh.
} 
a5 /// [ai]śaumye 20-5 dr [s $[s t \cdot]^{81} / / /$

a6 /// karsalñemem [ai]·[au] ///

a7 /// rñene [p]·os:ai [l] ///

b1 /// [dhu]n[āt] $[-] p \cdot[k]^{82} / / /$

b2 /// [ha $]^{83}$ nn agnir iva ga $[\text { cch } \cdot]^{84} / / /$

b3 /// n[au]talyñe $\cdot 30$ prati ${ }_{-85}^{85} / / /$

b4 /// hānāa [ya] (-) ${ }^{86}[m] \bar{a} c[\ddot{a}] / / /$

b5 /// • drụham śikṣata ///

b6 /// ltk $\cdot$ awlā[wat]tañ̃n [e] ///

b7 /// $[m 、]^{87}$ tu iśe wrantsai $[p \cdot]^{88} / / /$

\section{Transcription}

a1 /// yāmi • rāgam ca do(șam) /// Uv. 4.23b, c

a2 /// mäsketrä 23 ap(ramādam) /// Uv. 4.23d; Uv. 4.24a

a3 /// (snai yko)rñesa ylaiñäktäñ̃̃e (•) /// Uv. 4.24c

a4 /// (pandi)tah șek yamälyñent(ane aiśaumye •) /// Uv. 4.25b

a5 /// aiśaumye 25 drșț(adhārmika) /// Uv. 4.25d; Uv. 4.26a

a6 /// kärsalñemem ai(s')au(mye) /// Uv. 4.26c

a7 /// (yko)rñene p(r)os(k)ai l(kāskemane •) /// Uv. 4.27b

b1 /// (•) dhunāt(i pā)p(a)k(ām) /// Uv. $4.28 \mathrm{c}$

b2 /// (da)hann agnir iva gacch(ati) /// Uv. 4.29d

b3 /// nautalyñe $\cdot 30$ prati(vidhyate) /// Uv. $4.30 \mathrm{~d}$

b4 /// (pari)hānāya - mā cä /// Uv. 4.32c

b5 /// • drụ̂ham śikșata /// Uv. 4.33b

b6 /// (snai spe)ltk(e) awlāwattaññe /// Uv. 4.33d

b7 /// (pratibudhyadhva)m tu iśe wräntsai p(karsas) /// Uv. 4.34c

\footnotetext{
${ }^{81}$ This akșara should be the <șta $>$ of drsstadhārmika Uv. 4.26a.

${ }^{82}$ These akșaras should be $<\mathrm{dhu}>\mathrm{n} \bar{a}<\mathrm{ti}><$ pā $><\mathrm{pa}><\mathrm{kām}>$ of dhunāti pāpakām dharmām Uv. 4.28c.

${ }^{83}$ This akșara should be the $<$ ha $>$ of dahann Uv. 4.29 d.

${ }^{84}$ This akșara should be the $<$ ccha $>$ of gacchati Uv. $4.29 \mathrm{~d}$.

${ }^{85}$ This akșara should be the $<\mathrm{vi}>$ of pratividhyate Uv. $4.31 \mathrm{c}$.

${ }^{86}$ There is a folio abruption at this place. It is not clear enough if an akșara was eliminated by it. On the one hand, the traces of ink on the left and on the right sides of the abruption doesn't merge into one akșara because the first one is looking more like $\langle\mathrm{p}>$ or $\langle\mathrm{s}>$ and the second one is obviously $<\mathrm{m}>$. On the other hand, from the semantical point of view there is no need of any additional akșara.

${ }^{87}$ This akșara should be the $<\mathrm{m}>$ in virāma position of pratibudhyadhvam Uv. 4.34c.

${ }^{88}$ The rest of akṣara could be either of $<\mathrm{p}>$ or $<\mathrm{k}>$.
} 


\section{Restoration and tentative translation}

Uv. $4.23 \mathrm{~b} / / /$ yāmi

dharmasya bhavati hy anudharmacārī "...of the law, fulfills his duties (walks in the path of the Law)"

Uv. 4.23d /// mäsketrä

prahāya bhāgī śrāmanyārthasya bhavati "shares the benefit derived from the monastic life"

Uv. 4.24c (snai yko)rñesa ylaiñäktäñ̃̃e

apramādena maghavān "through heedfulness of Maghavan (= Indra)"

Uv. 4.25b șek yamälyñent(ane aiśaumye)

sadā krtyeșu pandititạ "a wise one permanently about [his] doings..."

Uv. $4.25 \mathrm{~d} / / /$ aiśaumye

atigṛhnāti panditah "a wise one surpasses"

Uv. 4.26c /// kärsalñemem ai(s')au(mye)

arthābhisamayād dhīrah "having clear understanding of things, a wise man"

Uv. 4.27b (yko)rñene p(r)os(k)ai l(kāskemane)

pramāde bhayadarśakah. "[the one, who is] looking with fear at negligence..."

Uv. $4.30 \mathrm{~d} / / /$ nautalyñe

sarvasamyojanaksayam "elimination of all that binds to the world"

Uv. $4.32 \mathrm{c} m \bar{a}$ cä ///

abhavyah parihạnaya "[the one who is] improper for a decrease"

Uv. 4.33d (snai spe)ltk(e) awlāwattaññe

anutthānam asamyamah "with a lack of endeavour and with uncontrolled [senses]"

Uv. $4.34 \mathrm{c}$ tu iśe wräntsai p(karsas)

tad angam pratibudhyantadhvam "O you! Recognize this!"

\section{Comments}

a1. Toch. B yāmi "doer", agent noun from $y \bar{a} m-,{ }^{89}$ corresponds to the last element of the Skt. compound anudharmacāri "[the one who] acts according dharma".

a2. Toch. B mäsketrä, 3sg. middle present from mäsk- "to be, become", 90 corresponds to Skt. bhavati, 3sg. present, "to be, become".

\footnotetext{
${ }^{89}$ ADAMS 2013, 532.

${ }^{90}$ ADAMS 2013, 491.
} 
a3. Toch. B snai ykorñesa, perl. sg., "without negligence; diligence"91 corresponds to Skt. apramādena, ins. sg., with the same meaning.

a3. Toch. B ylaiñäktä̃̃̃̃e, nom. sg., "pertaining to Indra, Indrahood" 92 corresponds to Skt. maghavān, nom. sg., "epithet of Indra".

a4. Toch. B șek "continually, perpetually" corresponds to Skt. sadā with the same meaning.

a4. Toch. B yamälyñentane, loc. pl., "doing”, verbal abstract from yām"to do, act", ${ }^{93}$ corresponds ${ }^{94}$ to the Skt. gerund krtyeșu, loc. pl., "to be done or performed".

a4. The Toch. B correspondence to Skt. panditah, nom. sg., "a wise one" should be restored as aiśaumye as in line a5.

a5. Toch. B aiśaumye, nom. sg., "a wise one" corresponds to Skt. panditah with the same meaning.

a6. The Skt. compound arthābhisamayād, abl. sg., "clear understanding of artha" was translated into Toch. B as a phrase with kärsalñemem,${ }^{95} \mathrm{abl}$. sg., "knowledge" as the last component. The first component could be restored as arthantse / ârth. ${ }^{96}$ Toch. B aiśaumye "a wise one" corresponds to Skt. dhirah with the same meaning.

a7. Toch. B ykorñene, loc. sg., "negligence" 98 corresponds to Skt. pramāde, loc. sg., with the same meaning.

a7. One can safely restor ${ }^{99}$ the Toch. B phrase proskai lkāskemane "seeing fear" corresponding to the Skt. compound bhayadarśakah, nom. sg., "[the one who is] looking with fear".

b1. Only Sanskrit text Uv. 4.28c.

b2. Only Sanskrit text Uv. 4.29d.

b3. Toch. B nautalyñe, obl. sg., "disappearance" 100 corresponds to the last component of Skt. composita sarvasamyojanakșayam "the destruction of all bounds [to samsāra]" acc. sg.

${ }^{91}$ ADAMS 2013, 559.

${ }^{92}$ ADAMS 2013, 563.

93 ADAMS 2013, 529

${ }^{94}$ yamälyñe "doing" would match much better to gerund, fem. from this root krtyā with meaning "act, doing". However, the loc. pl. of krtyā is krtyāșu.

${ }^{95}$ The correct form would be karsalñemem with $a$ in the first syllable (ADAMs 2013, 177).

${ }^{96}$ Cf. AdAms 2013, 56: ārth (n.[m.sg.]) 'meaning, sense' [ārth, arthantse, ārth//-, -, arthanma] arthantse karsalce 'knowledge of the meaning'

${ }^{97}$ Cf. ADAMS 2013, 113.

${ }^{98}$ ADAMS 2013, 559.

${ }^{99}$ Compare IOL Toch. 48 line a2: proskai lkāskem.

${ }^{100}$ ADAMs 2013, 371. 
b4. Sanskrit (Uv. 4.32c): abhavyah parihānāya. Lit. "[the one who is] improper for a decrease". One can suppose that in Toch. B it was translated as "[the one who is] not able to die or decrease" by a form of the verb cämp- ${ }^{101}$ "to be able to". May be the agent noun cämpamo was used.

b5. Only Sanskrit text Uv. 4.33b.

b6. One can safely restore the Skt. anutthānam, acc. sg., "want of exertion" as a Toch. B snai "without" speltke, obl. sg., "exertion". ${ }^{102}$

b6. Toch. B awlāwattaññe, nom. sg., "absence of self-control", abstract noun from adjective awlāwatte "uncontrolled, undisciplined", ${ }^{103}$ corresponds to Skt. asamyamah, nom. sg., with the same meaning.

b7. Toch. B $t u$, obl. sg., "that" corresponds to Skt. tat, acc. sg., with the same meaning.

b7. Toch. B iśe, a particle implying attention, corresponds to Skt. angam with the same meaning.

b7. Toch. B postposition wräntsai "against, opposite" and a 2pl, imperative, possibly pkarsas from kärs- "to know, understand, recognize", ${ }^{104}$ correspond to the Skt. pratibudhyantadhvam "to be aware of" $2 \mathrm{pl}$, imperative.

\section{Notes}

This fragment belongs to the fourth Udanavarga ${ }^{105}$ chapter named Apramādavarga.

Translation from Sanskrit is mostly a word by word one; however, there are some exceptions. Padas 4.28a-b, 29a-b, 30a-b, 31a-b, 32a-b are omitted as they are a mere repetition of padas $4.27 \mathrm{a}-\mathrm{b}$.

\section{A stotra fragment}

SI 2921/7 (Old number: SI B/3-6)

Find spot: Kuča, On-baš Min-Öy

Tocharian B

fig. 7

fig. 8

${ }^{101}$ For the meaning of cämp- cf. VyZHLAKOV 2020.

102 ADAMs 2013, 788.

103 ADAMS 2013, 32.

104 ADAMs 2013, 176.

${ }^{105}$ For the general context, cf. ĀNANDAJOTI BHIKKHU, 2007. 


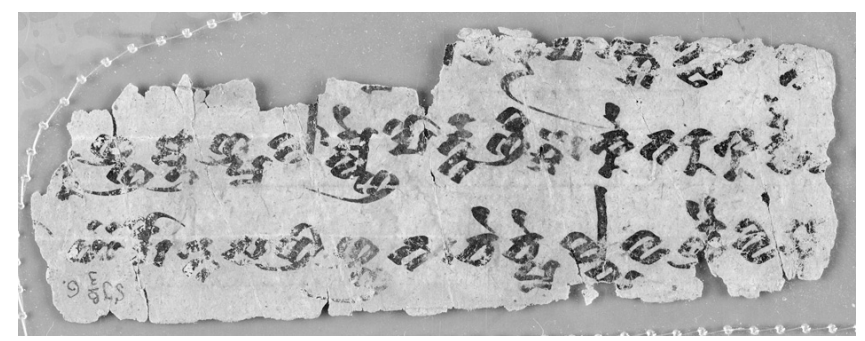

fig. 7: SI 2921/7 recto

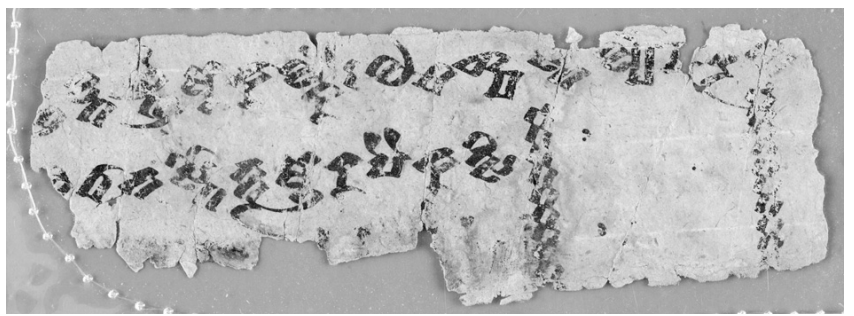

fig. 8: SI 2921/7 verso

\section{Material description}

Size (h x w, maximal): $3.7 \times 10.5 \mathrm{~cm}$. The right part of a leaf, preserving the lower right corner on the recto, and the upper right corner on the verso. On the fragment, three lines are still visible on both sides. One can assume that originally each side had at least 4 or 5 lines.

On the verso side, one can see two vertical lines of ornament made of doubled slanting strokes going up to the end of the page. This drawing is the usual device for marking the final leaf of a manuscript, following a colophon. This assumption fits the content of the line b2, which mentions the end of the copy of a text. Line b3 is very damaged: the paper has been erased, and the ink has fainted, so that one can see only the top of some akșaras.

\section{Metre $^{106}$}

The metrical character of the text is made sure by the double dots and by the instances of alternative word order. The complete metrical segments (āñmalāṣlñe porttar ñiś : ketara kartseś; yärpontasa ñiñ̃ana : ce cmeltsa warñai, pūdñäktäñ̃̃e akālko : ot șpä snai lyīpär) lead to the assumption that

${ }^{106}$ About Tocharian metre cf. PEYROT 2018. 
the metre was $4 \times 12$ syllables, rhythm $5 / 7$ (precisely 5/4+3). But the sentence to be found in line b2 was not metrical: it contained the title of the work, and probably the mention of the author of the text and the scribe.

\section{Transliteration}

a1 $/ / / \cdot[m] \cdot-[p] \cdot c[\bar{a}] \underline{r}[\cdot] p \cdot y s^{\prime} \cdot n t s \cdot c \cdot[y] n \cdot$

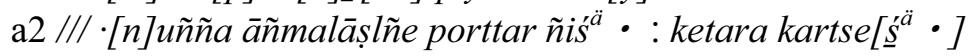

a3 /// o yärpontasa ñiññana: ce cmeltsa warñai wiko

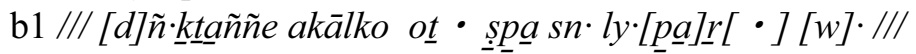

b2 /// [n] idhānastottra āra paikatsi

$\mathrm{b} 3 / / /-\cdot e \cdot e l \cdot e$

\section{Transcription}

a1 /// (śpāl)m(eṃ) (u)p(a)cār p(o)yś(i)nts(e) c(e) yn(eś)

a2 (yāmtsi : - - - - - - - - : - - - nuñ̃̃a āñmalāṣlñe porttar ñiś : ketara kartseś

a3 (yamașseñcai po skeye : warpoymar ok)o yärpontasa ñiññana : ce cmeltsa warñai wiko

b1 (yenträ - - : ) - - - - - - - - : - - - $(p \bar{u}) d \tilde{n}(\ddot{a}) k t a ̈ n \tilde{n} e$ akālko : ot șpä sn(ai) ly(ī)pär w.

b2 /// (pra)nidhānastotträ āra paikatsi

b3 /// no restoration possible

\section{Tentative translation}

a1 ...in order to make manifest the excellent practice of the omniscient.

a2 ...(please bestow) compassion, acknowledge me for the good of everyone

a3 (as making all efforts. May I enjoy the fruit) by my own meritorious acts. From this [present] existence onwards, may (the afflictions) disappear.

b1 (May my) wish of [attaining] Buddhahood (come true), and then entirely (the refuge?) ...b2 ...the writing [of this] Pranidhānastotra has come to the end.

\section{Comments}

a1. The words of this line should probably be restored as follows.

upacār - noun, obl. sg., a loan from Skt. upacāra- "practice, behavior, method". 
poyśintse - gen. sg., "the all-knowing one, omniscient", epithet and title of the Buddha, calque of Skt. sarvajña- "omniscient".

$c e-$ obl. sg. masc., of the demonstrative pronoun se of near deixis.

yneś - adverb, "really, obviously"; one could restore it as a part of the phrase yneś yāmtsi, infinitive, from the phrase yneś yām- "to make clear, manifest".

Accordingly, these would make a complete pāda: śpālmem upacār poyśintse ce yneś yāmtsi "in order to make manifest the excellent practice of the omniscient"; in other words, "to follow his example".

a2. The first word of the line remains conjectural. The ligature ends with $\langle\cdot n u\rangle$, but the upper part remains problematic: it may be $\langle s \cdot\rangle$, or a more complex ligature. The reading of $<\tilde{n} \tilde{n} a>$ is perfectly safe, and it would be arbitrary to suppose a mistake. Otherwise, this text does not show any spelling error. The nom. sg. - $\tilde{n} \tilde{n} a$, if it were the feminine of an adjective in -ññe, does not fit with ãñmalāsssälñe, which is masculine. Alternatively, an abstract in $-\tilde{n} \tilde{n} a$, (obl. sg. $-\tilde{n} \tilde{n} a i)$, does not fit in this context. The remaining option would be a verb form, the direct object of which would be "compassion". This would be a $2 \mathrm{sg}$. active of an imperative (V) based on a subjunctive stem in - $\tilde{n} \tilde{n}$ - (class XII), maybe from a denominative verb.

a2. āñmalāṣlñe is a verse form of añmalāṣsälñe, nom./obl. sg., "compassion".

a2. porttar - 2sg. middle imperative from $\bar{a} r t t \bar{a}$ - "to approve of, love, praise". A new form and obviously correct. For this variant of the imperative prefix $p(\ddot{a})$ - compare pokse from $\bar{a} k s$ - "to announce, proclaim". ${ }^{107}$

a2. ñiś - oblique of the $1 \mathrm{sg}$. person personal pronoun. The nominative form is identical but does not fit in the present context. This form cannot be simply the direct object of the preceding verb, because one would expect the suffixed pronoun $(-\tilde{n})$ of the 1 st person. Therefore, this pronoun ought to be constructed with a participial clause, which was made complete with the next segment. See the possible reconstruction of the text: ${ }^{108}$ porttar ñiś : ketara kartseś (yamașșeñcai po skeye) "acknowledge me, (as making all efforts), for the good of everyone", where yamașseñcai, obl. sg.

${ }^{107}$ ADAMS 2013, 41.

${ }^{108}$ However, it is important to mention that as there normally should be a syntactic break after the punctuation mark (double dots), this reconstruction supposes a misfit between metre and syntax. Otherwise the translation ought to be as follows:

a2 ... acknowledge me [with respect to?] compassion; for the good of everyone, ...

a3 ...(May I enjoy the fruit) by my own meritorious acts. 
nt-participle from yām- "doing"; po "all, every. each, complete"; skeye, obl. sg., "effort".

a3. The first word of the line ought to be restored as (ok)o, obl. sg., "fruit, result". As this text clearly contains a series of wishes, oko would be the complement of a verb meaning "to obtain, reach" or "to enjoy" in the optative, possibly wärp-. This would make a complete pāda: (warpoymar ok)o yärpontasa ñiññana.

a3. yärpontasa, perl. pl., "good deed, merit" (an equivalent of Skt. punya) and ñiññana, obl. fem. pl., "pertaining to me, my own" were put in a metrical order ${ }^{109}$ to impose the rhythm $4+3$ in the segment of 7 syllables.

a3. The last word of the line ought to be completed most probably as an optative form of wik- "drive off, disappear" either 3sg. middle wikoytär or 3pl. middle wikoy(e)ntär. ${ }^{110}$ The term kleś, (oblique, pl. kleśanma), loan from Skt. kleśa- "affliction, impurity, depravity, defilement" is commonplace $^{111}$ as the direct object of the causative (transitive) of the verb wik-. So the complete pāda can then be restored as follows: ce cmeltsa warñai wiko(yenträ kleśanma).

b1. akālk - nom./obl., sg. "wish". The form of the text is akälko with socalled mobile $-o$, which is attested in other metrical texts. This vowel alternates with $-\ddot{a}$ and with zero at the end of the word. A final $-k$ should have been written $<\underline{\mathrm{k}}>$. However, according to the requirements of metre, the $-o$ has been written here. The wish in question pertains to becoming a Buddha in the next life, based on the merits.

b1. snai lyipär - current phrase (as an equivalent of Skt. punya-) used as an adverb "without any rest; entirely, completely". ${ }^{112}$

b1. The last word of the line remains conjectural. One could restore wa(ste) "protection, refuge". ${ }^{113}$ This would refer to a commonplace notion, the threefold protection given by the Buddha, the Dharma and the Sangha.

\section{Notes}

This fragment has been used by Lévi for his edition of the Udānastotra, ${ }^{114}$ with the following comment:

\footnotetext{
${ }^{109}$ The normal (prose) order would be: ñiññana yärpontasa.

${ }^{110}$ ADAMS 2013, 652.

${ }^{111}$ For example, THT 1126 line a4 kleśanma wikäsṣäm.

112 ADAMS 2013, 602.

${ }^{113}$ ADAMS 2013, 634.

${ }^{114}$ Lévi 1933, 66.
} 
"Un fragment à Pétrograd semble appartenir au colophon:

1 tañ̃̃e akālk: os șpa snai lyipar

2 țānastottr āra paikatsi"

Lévi attributes this fragment to the Udānastotra. However, the connection with the Udannastotra seems to be wrong. Lévi assumes that for the $d$ of udāna the scribe wrote $\langle\mathrm{t}\rangle$ (utâna), but with the alternative $\langle t a\rangle$, namely the Fremdzeichen, transliterated currently as $<\underline{\mathrm{ta}}>$. But the Fremdzeichen $<\underline{\mathrm{ta}}>$ is never found together with the diacritic mark of long vowel $<\overline{\mathrm{a}}>$. Therefore, one should read $\langle d h \bar{a}\rangle$. The next decisive point is the reading of the preceding akșara: this sign could be $<\tilde{n} i>$, $<$ ṇi $>$, or perhaps $<$ śi $>$. One should quite definitely restore (pra) [n]idhānastotträ, a transposition of Skt. Pranidhānastotra.

In any case, the preceding text shows no common phrase with the conclusion of the Udānastotra. ${ }^{115}$

Since the notion of pranidhāna-, alternatively pranidhi- "solemn resolution, wish, vow" "116 is quite important in the Buddhist doctrine, a work with such a title is not unexpected. ${ }^{117}$ But an exact identification seems to be out of reach at this point.

\section{Fragment of a jātaka}

SI 2921/24 (Old number: SI B/3-13)

Findspot: Kuča, On-baš Min-Öy

Tocharian B

fig. 9

fig. 10

\footnotetext{
${ }^{115}$ See the edition and restoration by PINAULT 1990 and the comments by PEYROT 2016b.

${ }^{116}$ EDGERTON 1953, 360.

117 One would remember Samantabhadracaryāpranidhāna, also known as Bhadracarīpranidhānastotra and Arrya Bhadracarya Pranidhāna Rāja, the text which was popular in the region. Also the Samantabhadracaryā-pranidhāna text is written in the first person, as the text of SI 2921/7. However this text doesn not fit the Sanskrit version: http://gretil.sub. unigoettingen.de/gretil/1_sanskr/4_rellit/buddh/bst-108u.htm.
} 


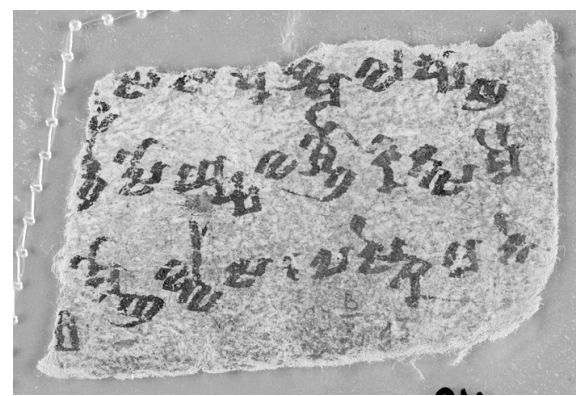

fig. 9: SI 2921/24 recto

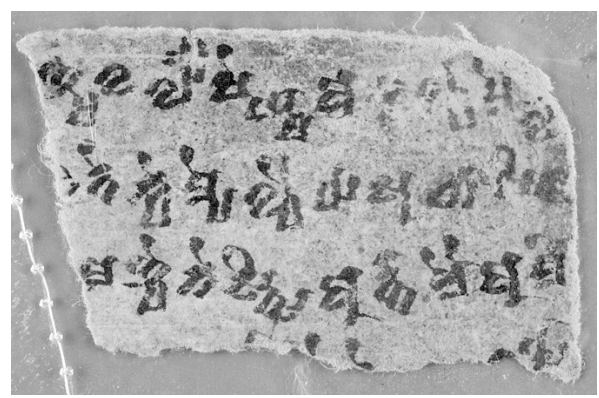

fig. 10: SI 2921/24 verso

\section{Material description}

Size ( $\mathrm{h} \times \mathrm{w}$, maximal): $3.3 \times 5.5 \mathrm{~cm}$. The right part of a leaf, preserving lower right corner of the presumed recto, and the upper right corner of the presumed verso. Based on the content, one cannot establish with safety what is the recto and the verso. On the fragment, three lines are still visible on one side, and four lines on the other side. Line b4 is much damaged so that one can see only the top of some akșaras. One can assume that originally each side had at least five lines. The text seems to be entirely in verse, judging from the double dot in a6, and the number in $\mathrm{b} 2$, and from instances of verse forms.

\section{Metre}

The metrical character of the text is made sure by the double dots and by the instances of metrically pressed forms (slyamoñ lwassa and teky empelye) as well as several verse forms. The definition of the metre remains uncertain. However, there are several instances of sequences of $7(4+3)$ syllables, and the final sequence of the pāda ought to be of 4 syllables (slyamoñ lwāsa :, teky empelye 10). Therefore, one may tentatively surmise that the metre was of 4 x 18 syllables, rhythm $7(4+3) / 7(4+3) / 4$.

\section{Transliteration}

a1 /// [lt] $s \cdot[r] s \cdot s \cdot a \tilde{n} m \cdot l \cdot s \underline{s}[e] m \tilde{n}$

a2 /// [rñe] soyșsawa śaul • rintsamai

a6 /// y'moñ $\cdot$ lwāsa : paskemane

b1 /// $\tilde{n}[e] m \cdot$ walo șeym $\cdot$ akalye $p[r] e \cdot[s] l l$ 
b2 //I [wa] teky empelye 10 subhāṣi[ta]

b3 /// mañye nestsi arttamai am [ā]m

$\mathrm{b} 4 / / /---\cdot \bar{a} \cdot e \cdot e--[\mathrm{ra}][\mathrm{p}] \mathrm{o}$

\section{Transcription}

a1 /// (au)lts(o)rs(a) s(e) añm(a)l(ā)șsemñ

a2 /// (perne)rñe soyșsawa śaul rintsamai

a3 /// (sl)y(a)moñ lwāsa : paskemane

b1 /// ñem walo șeym akalye pre(k)ṣl(e)

b2 /// (lyakā)wa teky empelye 10 subhāsita(gaveși)

b3 /// mañye nestsi arttamai amām

b4 //I - - - $\bar{a} \cdot e \cdot e--r a p o$

\section{Tentative translation}

a1....in brief, this one, out of pity

a2. ...I satisfied the glory, I gave up [my] life

a3. ...the flying animals. Observing

b1. ...was the king named ... The learning (ought) to be asked for (by myself)...

b2. ...(I suffered?) a dreadful disease. 10 (The king) Subhāșitagaveșin...

b3. ...I approved to become a servant. (I abandoned) the pride...

\section{Comments}

a1. The words of the line one should probably restore as follows.

aultsorsa-adverb, "in short, briefly", based on the verbal noun from the preterit participle from wälts- "to put together, press together.

añmalāșsemñ - causal (ending in - ̃̃) from añmalāṣse, equivalent of añmalāṣsälñe, abstract, "sympathy, pity, compassion". This form would be of the late layer of Tocharian B, featuring assimilation of a cluster of palatal consonants.

a2. The first word of the line ought to be restored as pernerñe, obl. sg., "splendor, glory".

a2. soyșsawa is a verse form with syncope for soyäsșawa, 1sg. active preterit from soy- "to satisfy".

a3. One knows already the fixed phrase lwāsa șlyamñana (THT 29 b8; to be restored in THT 343 a3), lit. "flying animals", referring to birds. Here the 
feminine plural șlyamñana of the agent noun șlyamo has been replaced by the masculine due to metrical requirements.

a3. paskemane is the $m$-participle from passk- "to protect; to observe (rules), practice, beware of".

b1. ñem - nom. sg., "name". It features here in the so-called naming construction with apposition to the proper name and the title of the person: "the king named N.N.".

b1. șeym is a late form of șaim, $1 \mathrm{sg}$. active imperfect from nes- "to be". ${ }^{118}$

b1. prekșle is a verse form with syncope for prekșalle, gerund (I), expressing obligation, from pärk- "to ask for, beg".

b2. The first word of the line remains conjectural. One could restore lya$k \bar{a} w a, 1$ sg. active preterit from läk- "to see", hence in this context "to suffer".

b2. teky is a sandhi form, metri causa, for teki, obl. sg., "disease, illness". With empelye, obl. sg., "terrible, horrible, dreadful, awful" composes a metrically pressed form teky empelye.

b3. mañye is a verse form with syncope of mañiye, obl. sg., "(male) slave, servant".

b3. amām - nom./obl., sg., "pride, arrogance"; here probably a direct object, complement of a verb meaning "to set apart, abandon".

\section{Notes}

The fragment belongs to a text which tells in verse stories of the past life (jätaka) of the Buddha in the first person, see the verbs in lines a5, b1, b3. Furthermore, the line b1 contains the typical sentence of conclusion, which gives the identification of a character of the distant past, in the 3sg. imperfect (ñem walo seym) ${ }^{119}$ This sentence corresponds to the so-called samodhāna, a finishing part of a jātaka in the Pāli Jātaka collection.

The king Subhāsitagaveșin is a well-known figure of Bodhisattva, which was the hero of a jātaka or avadāna. ${ }^{120}$

In Tocharian B, Subhāsitagavesin is found in several texts: IOL Toch. 115 a1, IOL Toch. 278 b1, THT 95 a6, THT 99 a6. Precisely, in Berlin fragments, the story of Subhassitagaveșin was told following the telling of the Aranemi-jātaka, the story of a very generous king, see the transition in THT

${ }^{118}$ Cf. Peyrot 2008, 58.

${ }^{119}$ Cf. THT 95 a1 (etre șaim), A 17a2, ThOMAs 1957, 74-75, 162.

${ }^{120}$ See the references in PANGLung 1981, 177. See in particular Mūlasarvāstivāda-Vinaya, Vinayakșudraka (T. 1451). Bodhisattvāvadānakalpalatā by Kṣemendra, No. 53 (see translation and analysis by STRAUBE 2009, 271-278); Avadāna-śataka, No. 38. 
95 recto. ${ }^{121}$ The story itself was told in drama form, as seen in the fragments THT 99 to $101 .{ }^{122}$ In short, the king in question is eager to learn a saying (subhāsita) of the Buddha. With this intention he meets a Yakșa (who is actually Indra/Śakra in disguised form) in the forest, and learns finally from him the saying (stanza) in exchange of his own life: in this goal the king prepares a gigantic fire and throws himself into it, which however changes itself immediately into a pond. Then he obtains to hear the saying and to spread it.

There is however some uncertainty concerning the SI 2921/24 fragment, partly because the fragmentary text does not offer any common word or phrase with the fragments THT 95, 99-101. This situation can be explained by a difference of genre, since the treatment in dramatic form in THT 99101 is quite extensive, with alternating prose and verse. It is not at all certain that the king who was named in SI 2921/24 b1 was identical to Subhāsitagaveșin, who is named later in line b2. The phrase "I gave up my life" (line a2) may apply to many Bodhisattvas. Then, it is possible that our text contained the successive telling of several jātakas in very abridged form (a type of text which is known otherwise) and in verse. And among them it contained the jātaka of Subhāṣitagaveșin.

\section{References}

ADAms, Douglas Q. 2013: A dictionary of Tocharian B. Revised and greatly enlarged. 2 vol. Series: Leiden studies in Indo-European, 10. Amsterdam: Rodopi.

Ānandajoti Bhikkhu 2007: A Comparative Edition of the Dhammapada. (2nd rev., 2007; last revised. 2018).

https://www.ancient-buddhist-texts.net/Buddhist-Texts/C3-Comparative-

Dhammapada/Comparative-Dhammapada.pdf

Bernhard, Franz 1965: Udānavarga. Band I: Einleitung, Beschreibung der Handschriften, Textausgabe, Bibliographie. (Sanskrittexte aus den Turfanfunden 10). Göttingen: Vandenhoeck \& Ruprecht.

EDGERTON, Franklin 1953: Buddhist Hybrid Sanskrit Grammar and Dictionary. Vol. II: Dictionary. New Haven: Yale University Press.

HÄRTEL, Herbert 1956: Karmavācanā. Formulare für den Gebrauch im buddhistischen Gemeindeleben aus ostturkistanischen Sanskrit-Hanschriften. Berlin: Akademie-Verlag.

LÉVI, Sylvain 1933: Fragments de textes koutchéens (Udānavarga, Udānastotra, Udānālamikāra et Karmavibhanga). Publiés et traduits avec un vocabulaire et une introduction sur le «tokharien». Paris: Imprimerie nationale (Cahiers de la Société Asiatique II).

Lundysheva O.V. 2019: "Rukopisi na Toxarskom B iz kollekcii Berezovskogo: fragment dvuiazychnogo teksta Udanavargi [Tocharian B manuscripts in M.M. Berezovsky' collec-

\footnotetext{
${ }^{121}$ Sieg \& Siegling 1953, 32.

${ }^{122}$ SIEG \& SiegLing 1953, 34-37.
} 
tion: a bilingual Udānavarga Fragment]. Mongolica-XXII. Saint-Petersburg: Peterburgskoe Vostokovedenie, 60-63.

OGIHARA Hirotoshi 2016: "Sanskrit-Tocharian B Bilingual Udānavarga Fragments Kept in the Russian Collection". In: Sergei Fedorovich Ol'denburg - uchenyi i organizator nauki [Sergei Oldenburg as a researsher and scientific administrator]. Ed. by I.F. Popova. Moscow: Nauka - Vostochnaia literatura, 223-235.

OGIHARA Hirotoshi 2018: Roshia shozō tokarago bunken ni kansuru oboegaki ロシァ所蔵ト カラ語文献に関する覚え書き [Remarks on the Tocharian manuscript housed in the Russian collection]. Tōkyōdaigaku gengo-gaku ronshū 東京大学言語学論集 [The University of Tokyo Journal of Linguistics] 40, 2018.9, e1-e41.

PANGLUnG, Jampa Losang 1981: Die Erzählstoffe des Mūlasarvāstivāda-Vinaya, analysiert auf Grund der tibetischen Übersetzung. (Studia Philologica Buddhica. Monograph Series III). Tokyo: Reiyukai Library.

PEYROT, Michaël 2007: An edition of the Tocharian fragments IOL Toch. 1 - IOL Toch. 822 in the India Office Library. London: IDP. http://idp. bl. uk.

PEYrot, Michaël 2008a: "More Sanskrit-Tocharian B bilingual Udānavarga fragments". Indogermanische Forschungen 113. Berlin: W. de Gruyter, 83-125.

Peyrot, Michaël 2008b: Variation and Change in Tocharian B. Amsterdam-New York: Rodopi.

PeYrot, Michaël 2016a: "Further Sanskrit-Tocharian bilingual Udānavarga fragments". Tocharian and Indo-European Studies 17. Copenhagen: Museum Tusculanum Press, 153-211.

PeYrot, Michaël 2016b: "The Sanskrit Udānavarga and the Tocharian B Udānastotra: a window on the relationship between religious and popular language on the northern Silk Road". BSOAS 79, 305-327.

Peyrot, Michaël 2018: "A Comparison of the Tocharian A and B Metrical Traditions". Language and Meter. Ed. by Dieter Gunkel and Olav Hackstein. Leiden: Brill, 319-345.

PINAUlT, Georges-Jean 1990: “Compléments à l'Udānālañkāra et à l'Udānastotra en koutchéen". In: Documents et archives provenant de l'Asie Centrale. Ed. by Haneda, Akira. Kyoto: Association Franco-Japonaise des Études Orientales, 51-69.

Monier-Williams, Monier 1899: Sanskrit-English Dictionary. Oxford: Clarendon Press.

SchMIDT, Klaus T. 2018: Nachgelassene Schriften. 1. Ein westtocharisches Ordinationsritual. Ed. by Stefan Zimmer. Bremen: Hempen Verlag, 1-159.

SiEg \& SiEgling 1953 - Sieg, Emil \& Siegling, Wilhelm. Tocharische Sprachreste, Sprache B. Heft 2: Fragmente Nr. 71-633. Aus dem Nachlaß hrsg. von Werner Thomas. Göttingen: Vandenhoeck \& Ruprecht.

Sieg \& Siegling 1983 - †Sieg, Emil \& †Siegling, Wilhelm. Tocharische Sprachreste. Sprache B. Teil I: Die Texte. Band 1. Fragmente Nr. 1-116 der Berliner Sammlung, neubearbeitet und mit einem Kommentar nebst Register versehen v. Werner Thomas edition. Ed. by Thomas, Werner. Göttingen: Vandenhoeck \& Ruprecht.

Straube, Martin 2009: Studien zur Bodhisattvāvadānakalpalatā. Texte und Quellen der Parallelen zu Haribhațtas Jātakamālā. Wiesbaden: Harrassowitz.

Thomas, Werner 1957: Der Gebrauch der Vergangenheitstempora im Tocharischen. Wiesbaden: Harrassowitz.

VyzHLAKOV M. 2020: "Ability and possibility in Tocharian A: the semantics of verbs yātand cämp- and their derivatives". Voprosy iazykoznaniia. Moscow: Izdatel'stvo Rossiiskoi Akademii Nauk (forthcoming). 